\title{
EKSISTENSI BUDAYA RIMPU MASYARAKAT SUKU MBOJO DI KABUPATEN BIMA
}

\author{
Astuti \\ Pascasarjana Universitas Islam Negeri Mataram \\ mbojoastuti@gmail.com
}

\begin{abstract}
Abstrak. Rimpu mengandung arti penutup kepala dengan menggunakan sarung sebagai penutup kepala dan sebagian tubuh. Rimpu merupakan pakaian tradisional khas Suku Mbojo yang berada di Kabupaten Bima yang masih eksis digunakan oleh perempuan asli Suku Mbojo hingga saat ini. Fokus permasalahan yang diuraikan dalam tulisan ini yaitu bagaimana aplikasi budaya Rimpu pada keseharian masyarakat Suku Mbojo di Kabupaten Bima dan bagaimana unsur budaya islam yang terkandung di dalam budaya Rimpu pada masyarakat Suku Mbojo diKabupaten Bima. Jenis penelitian ini adalah penelitian deskriptif dengan melibatkan masyarakat asli Suku Mbojo sebagai informan. Pengumpulan data dalam penelitian ini dilakukan melalui observasi langsung, interview, dan kajian literatur dari berbagai sumber. Data yang diperoleh kemudian dianalisis menggunakan metode analisis kualitatif.Hasil penelitian menunjukkan bahwa budaya Rimpu bagi masyarakat Suku Mbojo di Kabupaten Bima merupakan budaya yang sangat kental dan tidak dapat dipisahkan dari aktifitas kehidupan sehari-hari, masyarakat memiliki peran yang sangat peting dalam mempertahankan eksistensi budaya Rimpu masyarakat Suku Mbojo di Kabupaten Bima yang merupakan warisan budaya lokal yang berasal dari leluhur masyarakat Suku Mbojo di Kabupaten Bima. Simpulan dari penelitian ini yaitu budaya Rimpu masih memiliki eksistensi yang kuat dalam keseharian kehidupan masyarakat Suku Mbojo di Kabupaten Bima, dukungan dari masyarakat Suku Mbojo serta pemerintah sangat diperlukan dalam menjaga eksistensi Rimpu guna mempertahankan budaya lokal masyarakat Suku Mbojo di Kabupaten Bima.
\end{abstract}

Kata Kunci: Eksistensi Budaya, Rimpu, Suku Mbojo

\section{PENDAHULUAN}

Masyarakat Bima merupakan perpaduan dari berbagai suku, etnis dan budaya yang hampir menyebar di seluruh pelosok tanah air.Akan tetapi pembentukan masyarakat Bima yang lebih dominan adalah berasal dari imigrasi yang dilakukan oleh etnis di sekitar Bima. Daerah Bima merupakan suatu daerah yang kaya akan budaya dan adat istiadat, yang merupakan ciri khas masyarakat Bima itu. Namun saat adat istiadat tersebut perlahan-lahan mulai memudar, dan sulit untuk ditemukan.Sehingga tidak mengherankan banyak anak-anak atau para remaja Bima yang tidak mengetahui budayanya sendiri.

Adat istiadat dan budaya merupakan ciri khas suatu suku, Indonesia merupakan bangsa yang terkenal karena kaya akan adat istiadat yang berbeda pada tiap-tiap daerahnya. Budaya Rimpu merupakan cara berpakaian ciri khas masyarakat Suku Mbojo di Kabupaten Bima, khususnya pada kaum wanita, karena Rimpu dikenakan oleh perempuan asli Suku Mbojo.

Budaya merupakan keseluruhan kompleks yang meliputi pengetahuan, kepercayaan, kesenian, moral, keilmuan, hukum, adat istiadat, dan kemampuan yang lain serta kebiasaan yang didapat oleh manusia sebagai anggota masyarakat.Kebudayaan adalah semua hasil karya, rasa dan cipta masyarakat. Setiap daerah memiliki ciri khas kebudayaannya masing-masing, tidak terkecuali denganmasyarakat asli Suku Mbojo di Kabupaten Bima yang termasuk ke dalam wilayah Propinsi Nusa Tenggara Barat.Rimpu merupakan salah satu bentuk mode atau budaya berpakaian perempuan asli Suku Mbojo. .Budaya Rimpu sudah ada sejak masuknya islam di Kerajaan Bima pada tahun $1640 \mathrm{M}$ yang dibawa oleh tokoh-tokoh agama dari Gowa Makassar. Rimpu sejak saat itu 
menjadi salah satu identitas atau ciri khas masyarakat Suku Mbojo yang digunakan sebagai alat untuk mengkomunikasikan nilai, harapan, dan keyakinan kelompok sosial yang diikuti oleh anggotanya. Setelah masuknya islam, kerajaan bima berubah menjadi kesultanan bima yang menjunjung tinggi syari'at islam dalam aplikasi kehidupan masyarakat di seluruh wilayah kesultanan bima pada saat itu. Berbagai kebijakan istana mengacu pada al-qur'an dan hadis sebagai pedoman hidup manusia, tidak terkecuali dalam hal menutup aurat bagi kaum perempuan Suku Mbojo. Terdapat semboyan yang sejak dahulu dijunjung oleh masyarakat Bima, yakni "Mori ro made na Dou Mbojo ede kai hukum Islam-ku", yang artinya "Hidup dan matinya orang Bima harus dengan hukum Islam", yaitu Al-Qurean dan Hadis itu sendiri.

Keberadaan Rimpu dalam aplikasi kehidupan masyarakat Suku Mbojo akhirakhir ini mengalami penurunan, salah satunya disebabkan oleh perkembangan mode serta arus modernisasi yang intens terjadi di dalam kehidupan masyarakat khususnya di Kabupaten Bima. Budaya Rimpu jarang terlihat digunakan oleh kalangan remaja putri Suku Mbojo. Saat ini, Rimpu hanya terlihat dipakai oleh kalangan perempuan yang telah berusia lanjut. Eksistensi budaya Rimpu mengalami penurunan kuantitas pengguna di kalangan masyarakat Suku Mbojo di Kabupaten Bima yang menyebabkan budaya Rimpu menjadi budaya yang terlupakan. Budaya Rimpu merupakan sebuah tradisi dalam dimensi budaya masyarakat Suku Mbojo yang telah hidup dan berkembang sejak islam masuk ke wilayah kerajaan bima. Rimpu mengandung nilai-nilai keislaman seperti menjaga aurat bagi kaum perempuan dalam menjalankan aktifitas kehidupan bermasyarakat serta menjaga nilai kesopanan dalam berbusana.

\section{METODOLOGI}

Jenis penelitian yang digunakan dalam penelitian ini adalah penelitian deskriptif dengan melibatkan masyarakat asli Suku Mbojo sebagai informan. Pengumpulan data dalam penelitian ini dilakukan melalui observasi langsung, interview, dan kajian literatur dari berbagai sumber. Data yang diperoleh kemudian dianalisis menggunakan metode kualitatif. Metode kualitatif sering juga disebut metode penelitian naturalistik, karena penelitiannya dilakukan pada kondisi yang alamiah.

\section{HASIL DAN PEMBAHASAN}

Rimpu merupakan pakaian yang menutup aurat bagi masyarakat Suku Mbojo di Kabupaten Bima.Rimpu memilki banyak manfaat salah satu diantaranya yaitu dipakai pada saat menghadiri acara resmi. Mayoritas masyarakat Suku Mbojo dalam mengembangkan nilai adat istiadat dan tradisi budaya menggunakan Rimpu untuk menunjukkan identitas dan ciri mereka kepada masyarakat luarsehingga Rimpu sejak dahulu dikenal sebagai penguat keagamaan masyarakat Suku Mbojo. Penggunaan Rimpu pada zaman dahulu merupakan suatu kewajiban bagi kaum perempuan Suku Mbojo, Rimpu harus dipakai ketika mereka keluar rumah. Merupakan suatu pelanggaran bagi perempuan Suku Mbojo yang tidak menggunakan Rimpu saat beraktifitas di luar rumah, sehingga perempuan Suku Mbojo selalu menggunakannya. Keyakinan dan kepercayaan perempuan Suku Mbojo terhadap nilai-nilai yang terkandung pada Rimpu menjadikan mereka kokoh dalam menegakkan nilai agama.Pada masa pemerintahan Sultan Muhammad Salahuddin, peradaban Islam di Dana Mbojo sangat berkembang dan berjaya. Salah satunya dengan tetap mempertahankan eksistensi Rimpu sebagai salah satu budaya Bima yang khas.

Rimpu digunakan oleh mereka yang sudah balig atau menikah, dalam agama atau trend sekarang disama artikan dengan kerudung. Namun pada beberapa refrensi, kerudung di Indonesia baru terkenal pada tahun 1980-an. Rimpu memiliki multifungsi dalam menyikapi jamannya pada saat itu. Pertama, Rimpu merupakan identitas keagamaan, sehingga pada bagian ini dengan adanya perkembangan dakwah di Bima yang cukup pesat, maka kaum wanita mulai mempelajari dan memaknainya sebagai suatu nilai-nilai luhur. Kedua, Rimpu 
dikombinasikan dengan budaya lokal masyarakat pada saat itu yaitu kebiasaan menggunakan sarung tenun dalam aktifitas sosial. Intergrasi ini menjadikan icon budaya Bima yang mulai berkembang. Ketiga, Proteksi diri kaum hawa ketika melakukan interaksi sosial. Klimaks kondisi ini terjadi ketika jaman kolonial Belanda dan Jepang. Keempat, Rimpu merupakan alat pelindung terhadap kondisi lingkungan yang buruk, disisi lain juga Pembajakan Makna dan Budaya.

Rimpu, terdiri dari 2 model, yaitu pertama Rimpu mpida,, khusus buat gadis Bima atau yg belum berkeluarga. Model ini juga sering disebut cadar ala Bima,, Dalam kebudayaan masyarakat Bima, wanita yg belum menikah tidak boleh memperlihatkan wajahnya, tapi bukan berarti gerak-geraknya dibatasi.Hal ini menunjukan budaya yang diciptakan oleh para mubalig sudah mengakar sampai pelosok desa. Namun dengan moderenisasi yang salah diartikan membuat identititas tersebut rapuh termakan jaman, sungguh menyayangkan. Kedua Rimpu colo,, Rimpu jenis ini diperuntukan buat ibu-ibu rumah tangga. Toleransi agar mukanya sudah boleh kelihatan oleh masyarakat luas. Di pasar-pasar tradisional, masih bisa ditemukan ibu-ibu yang memakai Rimpu dengan sarung khas dari bima (tembe nggoli).

Setiap daerah memiliki jeniskain yang berbeda sesuai dengan caradan proses pembuatannya. Masyarakattradisioanl mengenal dalam pembuatan kain menggunakan bahan-bahandari alam sekitarnya. Mulai dari bahanbenang, sampai bahan pewamamenggunakan olahan dari berbagaijenis kombinasi yang berasal daritumbuh-tumbuhan. Pengetahuna lokal dalam pembuatan pakaian itu didapatkan dari proses panjang yang diturunkan secara baik oleh nenekmoyang kepada generasikegenerasi.Jenis-jenis kain tradisionaltermasuk pula tenun ikat di NusaTenggara Barat, masih banyak yang belum dieksplorasi. Salah satu jenis kain tenun tradisonal yang berasal dari Suku Mbojo di Kabupaten Bima adalah tenun Tembe Nggoli, proses pembuatannya dimulai dari memintal benang hingga proses menenun dilakukan. Penenunan ini biasanya dilakukan oleh perempuan-perempuan asli Suku Mbojo, mereka biasa menyebutnya dengan muna. Perempuan Bima hanya menggunakan Tembe (sarung) khas Bima untuk Rimpu. Budaya Rimpu ini juga melahirkan budaya baru yakni budaya menenun sarung (muna tembe), menenun merupakan salah satu bentuk matapencaharian bagi masyarakat Bima pada umumnya, khususnya bagi para perempuan. Budaya muna tembe ini dilakukan secara terus menerus, tidak hanya bagi ibu-ibu bahkan para remaja juga menekuni tenunan tradisional Bima ini, meskipun hanya sebagian kecilnya saja.

Rimpu memiliki arti menutup yang dimaknai dalam kegiatan menutup bagian kepala bagi kaum peempuan Suku Mbojo. Rimpu memiliki kesamaan dengan model kerudung atau jilbab. Rimpu merupakan ciri khas masyarakat Suku Mbojo yang berkembang setelah masuknya islam di kerajaan bima, memiliki bentuk dan ciri yang khas serta mengandung nilai keislaman dalam kewajiban menutup aurat bagi kaum perempuan sebagaimana yang telah diperintahkan di dalam Al-Qur'an dan Hadis. Tata cara mengenakan rumpuyakni, di sebelah kanan Rimpusarungnya sampai ke bawah, kalau disebelah kiri sarungnya dinaikkansampai ke pundak. Rimpu merupakanpakaian yang menutup bagian luarsaja.

Berbagai upaya dilakukan oleh masyarakat serta pemerintah daerah dalam meningkatkan eksistensi dan menjaga keberadaan budaya Rimpu melalui berbagai kegiatan seperti kegiatan Baksos dan Pentas Seni Budaya Bima Dompu yang dilakukan oleh perkumpulan masyarakat Bima Dompu di Tangerang pada bulan Mei 2019 kemarin yang bertujuan untuk menunjukkan kecintaan mereka terhadap budiluhur budaya Suku Mbojo. Kegiatan lain yang dilakukan yaitu pada tahun 2015 yang diselenggarakan oleh pemerintah kabupaten dompu dalam rangkaian acara Tambora menyapa dunia yang di selenggarakan di alun-alun pemerintah kabupaten dompu. Kegiatan yang 
dilakukan pada acara tersebut yaitu parade dengan menggunakan Rimpu yang diikuti oleh kurang lebih 15.000 orang peserta dan kegiatan tersebut memecahkan rekor MURI. Kota Bima pada 13 Oktober 2019 kemarin juga menggelar kegiatan yang sama yaitu parade dengan menggunakan pakaian adat Suku Mbojo yaitu Rimpu dan memecahkan rekor MURI dengan jumlah peserta sebanyak 20.165 orang peserta. Peserta yang mengikuti kegiatan tersebut berasal dari wilayah Kota dan Kabupaten Bima.

Tradisi rimpu mempunyai pengaruh yang positif bagi pengembangan budaya dan sekaligus sebagai bukti besarnya pengaruh budaya terhadap perkembangan Islam di darah Bima. Budaya Rimpu bagi masyarakat Suku Mbojo di Kabupaten Bima merupakan budaya yang sangat kental dan tidak dapat dipisahkan dari aktifitas kehidupan seharihari, masyarakat memiliki peran yang sangat peting dalam mempertahankan eksistensi budaya Rimpumasyarakat Suku Mbojo di Kabupaten Bima yang merupakan warisan budaya lokal yang berasal dari leluhur masyarakat Suku Mbojo di Kabupaten Bima.

\section{SIMPULAN}

Rimpu merupakan pakaian tradisional khas Suku Mbojo yang berada di Kabupaten Bima yang masih eksis digunakan oleh perempuan asli Suku Mbojo hingga saat ini. Budaya Rimpu masih memiliki eksistensi yang kuat dalam keseharian kehidupan masyarakat $S u k u$ Mbojo di Kabupaten Bima, dukungan dari masyarakat Suku Mbojo serta pemerintah sangat diperlukan dalam menjaga eksistensi Rimpu guna mempertahankan budaya lokal masyarakat Suku Mbojo di Kabupaten Bima.

\section{DAFTAR PUSTAKA}

Ramadhan Risca Ariska. 2018.Rimpu and Symbolization of Female Identity in Bima Community. Advances in Social Science and Humanities Research. 4Th PRASASTI International Converence on Recent Linguistics Research 2018. Vol. 166. 267-270.

Aulia Raihlah Nur. 2013. Rimpu: Budaya dalam Dimensi Busana Bercadar
Perempuan: Jurnal Studi Al-Qur'an. Vol. 9, No. 2. 1-11

Loir, Henri Chambert dan Siti Maryam R. Salahuddin (penyunting), $\mathrm{Bo}^{\text {ce }}$ Sangaji Kai : Catatan Kerajaan Bima, Edisi II. Jakarta: Yayasan Pustaka Obor Indonesia, 2012.

Siti Lamusiah. 2013. Estetika Budaya Rimpu pada Masyarakat Bima: Kajian Religiusitas.Jurnal Media Bina lmiah.Vol. 7, No. III.

Sugiyono. 2011. Metode Penelitian Kuantitatif Kualitatif dan R\&D. Bandung: Alfabeta.

Ulya Nurul Karimatil. 2017. Resepsi Konsep menutup Aurat dalam Tradisi Pemakaian Rimpu (Studi Living Qur'an-Hadis di Desa Ngali Kec. Belo Kab. Bima-NTB.Al-Bayan: Jurnal Studi Al-Qur"an dan Tafsir.Vol. 2, No. 2. 147-162.

Jayanti I Gusti Ngurah. 2017. Budaya Rimpu dalam Masyarakat Bima (Mbojo): Jnana Budaya. Vol. 22, No. 2. 315330.

Rahmi. 2016. Makna Rimpu Sebagai Media Komunikasi Nonverbal Bagi Perempuan Bima.Jurnal Komunikasi dan Kebudayaan. Vol. III, No. 1. 6979.

Aksa. 2018. Rimpu, Tradisi dan Kespresi Islam di Bima: MIMIKRI. Vol. 4, No. 1. 83-91. 